\title{
Analysis of Historical River Floods - A Contribution Towards Modern Flood Risk Management
}

\author{
Jochen Seidel ${ }^{1}$, Paul Dostal ${ }^{2}$ and Florian Imbery ${ }^{3}$ \\ ${ }^{1}$ Institute of Hydraulic Engineering, \\ Department of Hydrology and Geohydrology, University of Stuttgart, Stuttgart \\ ${ }^{2}$ German Aerospace Center, Bonn \\ ${ }^{3}$ German Meteorological Service (DWD), \\ Department Climate and Environment Consultancy, Offenbach am Main
}

Germany

\section{Introduction}

The occurrence of several extreme flood events in Central Europe in the last two decades, in particular the flood along the Elbe River in 2002, and the resulting damage have shown shortcomings in the field of flood protection and have raised discussions on how to deal with flood risk in the future. As a consequence, the German Federal Ministry of Education and Research funded the "Risk Management of Extreme Flood Events" (RIMAX) research programme, which aimed at the development and implementation of improved instruments for flood risk management (www.rimax-hochwasser.de).

A first step towards modern flood risk management is the assessment of the flood risk. Many installations for flood protection are usually designed for a specific flood discharge, commonly the 100 year return period is used. Therefore, extreme value statistics and the calculation of return times are an important and wide spread tool to assess the flood risk in river catchments, which is a fundamental part of flood risk management. One major drawback of extreme value statistics is the underlying data series, which often comprise only a few decades. The occurrence of flood events frequently shows a cyclic behaviour. Therefore, extreme value statistics based on short data series often do not reflect or capture the behaviour of a specific catchment sufficiently.

Models for risk assessment are only as good as the data used in their development. The development of detailed, calibrated and verified flood modelling is therefore essential in order to accurately assess exposure. This requires good records of data such as rainfall, stream gauge and tidal information as well as historical flood levels and especially historical flood reports including historical hydrometeorological data (Middelmann, 2007). The analysis of historical flood events can shed some light on flood triggering mechanisms and can be applied to extend data series into the past in order to improve the validity of return times. Therefore, there's a need to assess extreme flood events with a high magnitude and a low probability of occurrence. Hence, one of the fundamental deficiencies of flood risk management often is the 
lack of information or knowledge of extreme flood events which occurred in the past. Even if there is some information of historical flood events (e.g. flood marks on old buildings) in a specific river basin, it is still difficult to convert this qualitative historical information into a quantity which can be used to evaluate extreme discharges, for example. This deficit can be overcome by a detailed reconstruction of past flood events.

In this chapter, we present a case study for the Neckar catchment in south west Germany, where different independent methods are applied to reconstruct and analyse two historical flood events in 1824 and 1882. The weather conditions which led to these floods were reconstructed by using the information from various historical sources (e.g. archive records, qualitative and quantitative meteorological observations, contemporary newspaper reports, chronicles, etc.). Discharges in the Neckar catchment for these two flood events were simulated with a water-balance model and compared with the estimated discharges on the basis of historical river morphology data such as cross profiles and water surface slopes. These results were then used to extend the data series for a gauging station in the Neckar River, where modern discharge data exits from 1921 onwards. By including the discharges from the extreme floods in the $19^{\text {th }}$ century the data series for this site could be extended by 100 years into the past. This information leads to a better assessment of the river discharge characteristics and to a more stable calculation of return times.

This chapter presents a geographic description of the study area followed by an overview about state of the art research in this particular subject. Afterwards, the data basis for reconstructing the extreme flood events and the methods applied for this case study are described. Finally, the advantages and limitations of the case study are discussed.

\section{Study area}

The Neckar River basin (area: $14,000 \mathrm{~km}^{2}$ ) is located in the south west part of Germany and is a tributary of the Upper Rhine Valley (Fig. 1). The elevation in the Neckar catchment ranges from $1020 \mathrm{~m}$ above sea level (a.s.l.) in the Black Forest to $78 \mathrm{~m}$ a.s.l. at Mannheim; the mean value is $435 \mathrm{~m}$ a.s.l.

The precipitation in the region is strongly modified by the local orography. The highest mean annual precipitation values of $2000 \mathrm{~mm}$ are recorded in the mountain ranges of the northern Black Forest. Towards the eastern part of the study site, the mean annual precipitation decreases to values of approximately $800-1000 \mathrm{~mm}$. The Neckar is the principal tributary of the Upper Rhine, rises in the eastern Black Forest and is $367 \mathrm{~km}$ long. It is the river with the largest catchment in the Federal State of Baden-Württemberg, south west Germany. The Neckar passes through the cities of Tübingen, Stuttgart and Heidelberg and flows into the River Rhine at Mannheim (Fig. 1). The Neckar is navigable from Plochingen at the inflow of the Fils ( $\mathrm{km} \mathrm{202.5)}$ to Mannheim (at the river mouth) and beside the rivers Rhine and Main, it is one of the three main waterways in Baden-Württemberg. Several industrial centres are situated in the Neckar basin around Stuttgart and Mannheim. These areas, therefore, constitute a high flood damage potential.

One of the most extreme and devastating floods in south west Germany was the catastrophic flood event in October 1824, which also affected the adjacent areas in southern Germany and eastern France. A further severe flood event occurred in December 1882. The first gauging station at the Neckar River was installed in Heilbronn in 1827 (Centralbureau für Meteorologie und Hydrographie, 1889). Starting in 1881, continuous and systematic 


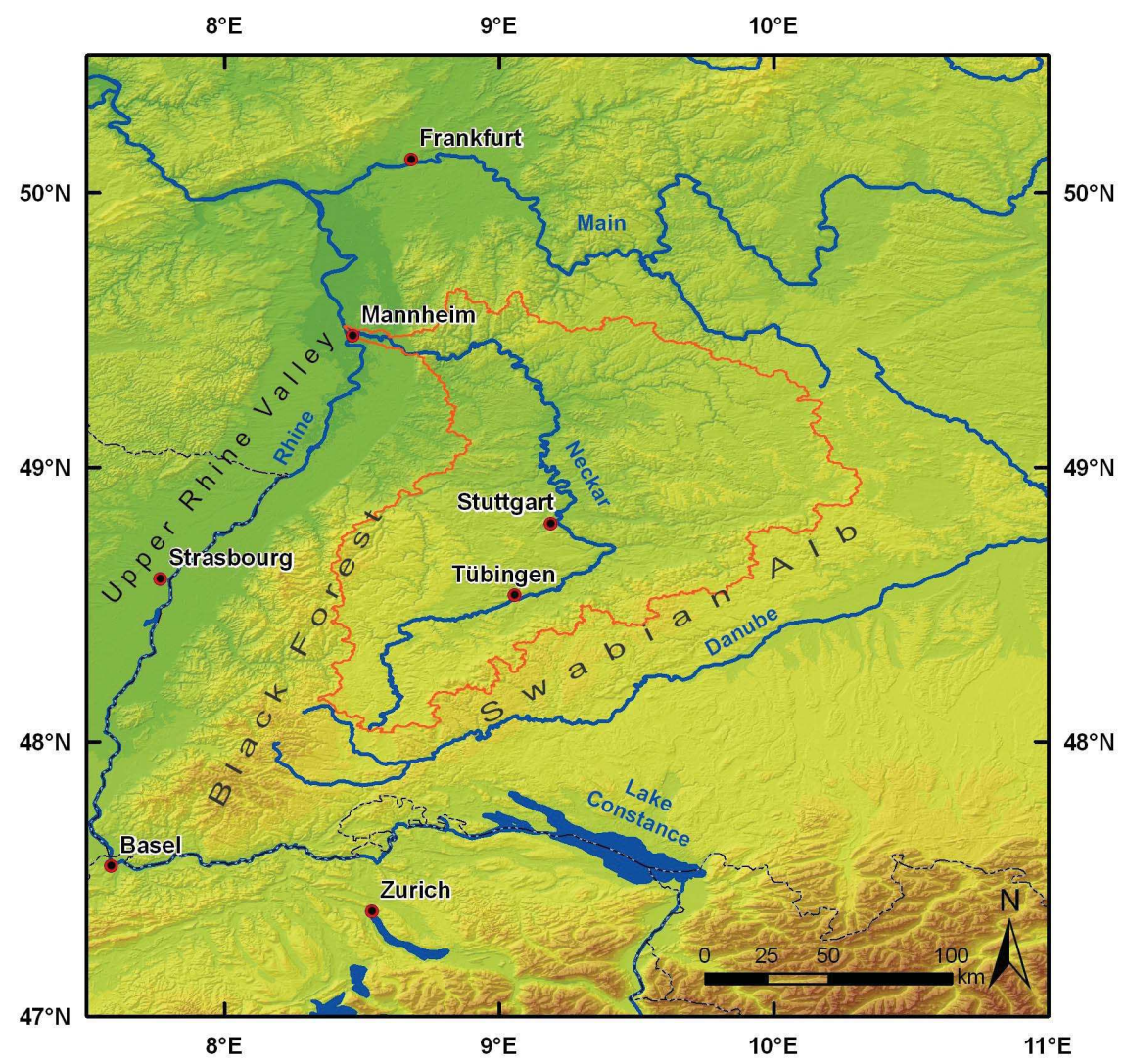

Fig. 1. Overview map of the study area. The orange line depicts the catchment of the Neckar River

measurements of the water levels were carried out at six gauging stations along the Neckar River (Statistisch-Topographisches Bureau, 1883). At present, 17 gauging stations are installed along the main channel of the Neckar.

\section{Approaches and methods for reconstructing historical flood events}

As stated above, the information from historical documents has a great potential for the reconstruction of floods in the past and can be informatively helpful for contemporary flood risk management. Therefore, a lot of research activities in the field of historical hydrology have been carried out in the past years, e.g. in the RIMAX research programme or the EU funded project "Systematic, Palaeoflood and Historical Data for the Improvement of Flood Risk Estimation" (SPHERE). A review of scientific methods using historical data for improving flood risk estimation is given by Benito et al. (2004). Furthermore, Kundzewicz \& Brázdil (2006) published a special issue on the field of historical hydrology. 
One approach to reconstruct historical flood events, which was used in this case study, is based on the analysis of a flood triggering meteorological situation on a regional scale. This approach is reliant on information from historical data, such as meteorological and hydrological measurements, to reconstruct past flood events, to identify their hydrometeorological causes and to quantify the areal precipitation in a specific river catchment. The reconstruction of the meteorological situation allows the analysis of a river provided that a run-off model for it is available to implement meteorological data. Restricting such events to rainfall makes the flood reconstruction independent from river profiles and discharge values. This avoids also uncertainties arising from the instationarities of the river characteristics caused by river morphology changes during past centuries. One of the first steps to analyse the 1824 and 1882 flood events was to find the mostly entire material in archives and libraries as well as in private estates.

\subsection{Information from regional historical meteorological data}

For the analysis of the 1824 and 1882 flood events in south west Germany, a variety of different data sets were consulted. A detailed overview of the collected and analysed data was given by Seidel et al. (2009), Bürger et al. (2006), Sudhaus et al. (2008), Dostal et al. (2007) and Straub (2007). The main difference between the datasets of 1824 and 1882 is the different quantity and quality of the meteorological measurements. In 1824, most meteorological observations were locally conducted by scientists or other people, but these measurements were not necessarily linked or standardized. However, one local meteorological network was already founded in south west Germany by 1824 . These meteorological observations were the result of the first standardized measurements in south west Germany and already used in contemporary scientific publications related to the flood catastrophe in 1824. Schübler has published the daily precipitation amounts from five meteorological stations for the extreme flood event at the end of October and the beginning of November 1824 (Schübler, 1825). These data are still only fractional or unpublished and were firstly used by Bürger et al. (2006). The location of the sites with meteorological measurements in 1824 is depicted in Figure 2 .

In 1882 , the data source is fundamentally different. During the second half of the $19^{\text {th }}$ century, meteorological observation networks were founded and the data were regularly exchanged and published in newspapers or other chronicles. The first meteorological congress in 1875 led to the establishment of standards, and the same time meteorological data were regularly published by various national weather observation agencies, e.g. the Meteorologische Beobachtungen in Deutschland (Germany), Annalen der Schweizerischen Meteorologischen Zentralanstalt (Switzerland) and monthly reports of the forest meteorological Stations in Alsace-Lorraine (now France). For south west Germany and the adjacent regions in northern Switzerland and eastern France, daily observations from 46 stations were available for the reconstruction of the meteorological conditions in 1882. The historical meteorological data for 1824 and 1882 usually contain three daily measurements of air pressure, air temperature, relative humidity, wind direction and strength and degree of cloudiness. Mean daily temperatures $(\mathrm{T} \bar{x})$ were derived according to equation 1

$$
T \bar{x}=\frac{\left(T_{7}+T_{14}+2 \cdot T_{21}\right)}{4}
$$

where $T_{7}$ is the temperature reading at 7 a.m., $T_{14}$ ist the reading at 2 p.m. and $T_{21}$ is the reading at 9 p.m. This formula was commonly used at meteorological stations in Germany 


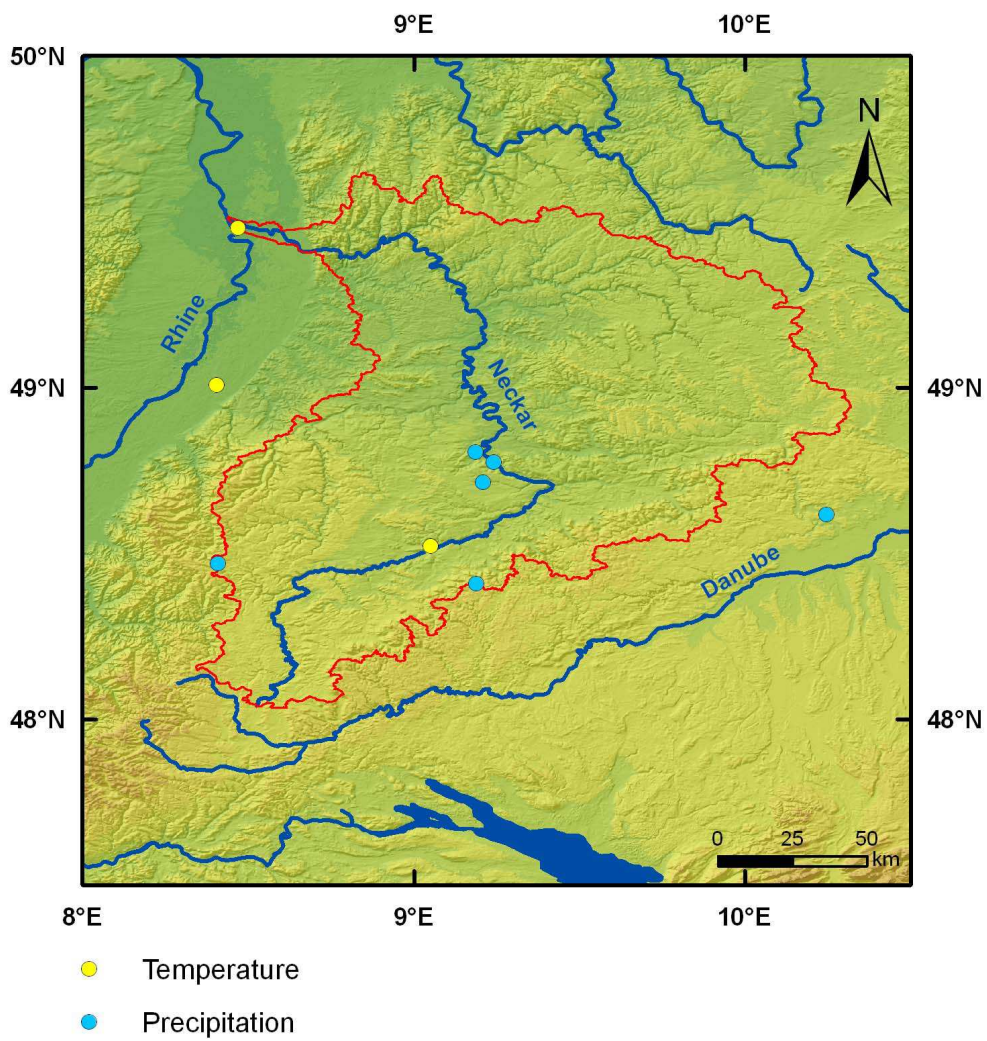

Fig. 2. Locations with meteorological observations in 1824

before hourly automatic readings were established. Additional information was often supplied by weather symbols indicating the occurrence and duration of phenomena such as precipitation, fog, etc. Beside air pressure and air temperature, quantitative precipitation values were also available. Daily precipitation amounts for various sites from December 25 to 281882 were published by Honsell and Tein (1891). Daily precipitation amounts for the complete year 1882 were also available for 26 stations in the Alsace-Lorraine Region from the French Weather Service Méteo-France. All in all, daily precipitation amounts during the flood event of December 1882 were available for more than 100 stations in southern Germany and adjacent areas in northern Switzerland and eastern France. For the interpolation of daily areal precipitation, only the data from stations within or in the vicinity of the Neckar catchment were used (c.f. Figure 3).

Additionally to the observed meteorological data, contemporary newspaper reports and documentary sources were also evaluated for both flood events. These documents revealed various important and detailed information like local weather conditions before and during the flood events and height of water levels at different locations along the rivers and damage reports. 


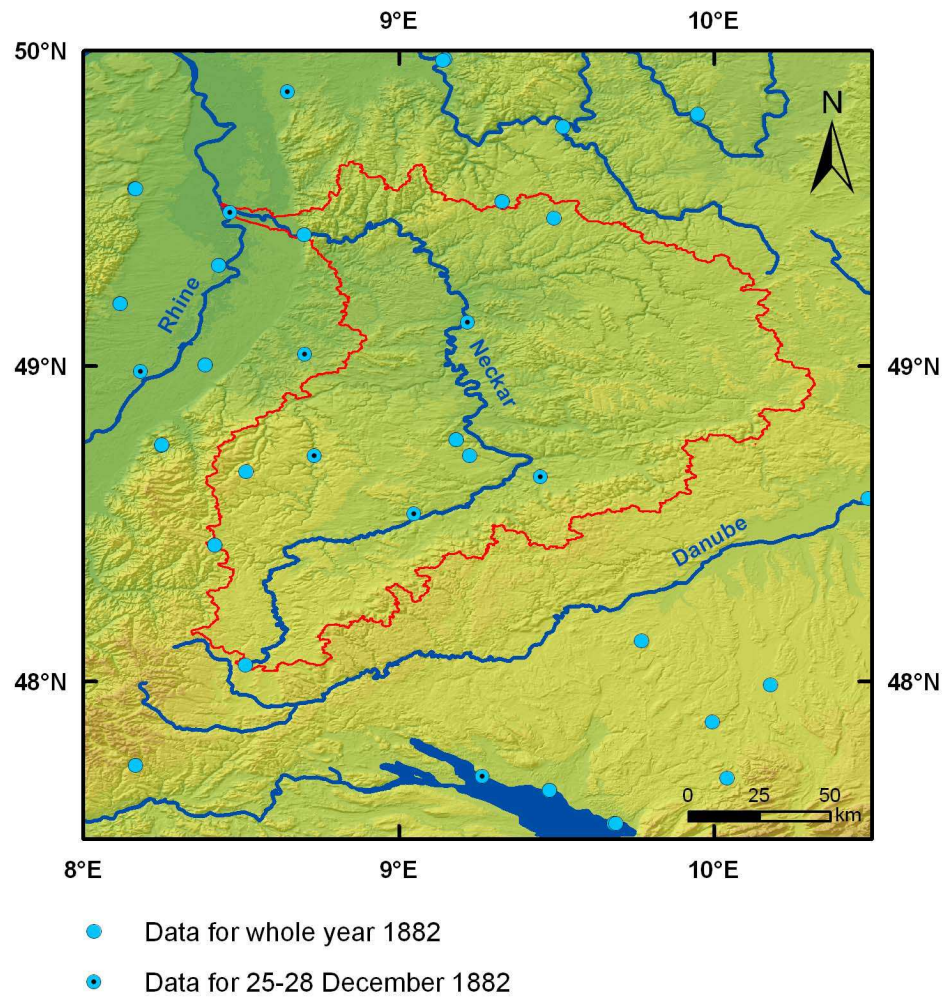

Fig. 3. Locations with meteorological observations in 1882

\subsection{Information from large scale meteorological data}

The atmospheric circulation pattern before and during the both flood events was derived from two different datasets. A historical meteorological dataset with climate data distributed over Europe (Barriendos et al., 2003) was used for determining the circulation patterns for the 1824 flood event. For the second flood event in 1882, the EMULATE data set (Ansell et al., 2006) was used, which comprises daily SLP-Grids with a $5^{\circ}$ resolution for Europe and the North Atlantic.

\section{Regionalisation of historical data}

\subsection{Discharge simulation: prerequisites and assumptions}

The discharges for the 1824 and 1882 flood events were simulated with the water balance model LARSIM (Ludwig \& Bremicker, 2006). Due to the fact that the historical station network was less dense than the station density currently implemented in the LARSIM model, it was necessary to create daily temperature and precipitation grids for the study area. The procedures on how these grids were derived are described in the following subsections. From these gridded data sets, the corresponding meteorological parameters (temperature, precipitation) were derived for the station sites used in the LARSIM run-off model. 
The LARSIM model is based on a $1 \mathrm{~km}$ grid and incorporates different meteorological parameters (e.g. air temperature, precipitation, air pressure, wind direction, wind velocity) as well as 16 land-use classes and current river profiles. Due to the circumstance that only a few of these parameters could be reconstructed on the basis of historical data, some simplifications regarding the model parametrisation were made. The land use was disregarded because several studies (e.g. Bronstert et al. (2003); Haag et al. (2005); Ott \& Uhlenbrook (2004)) have shown that this factor had only a small influence on discharge values during advective hydrometeorological extreme events. Therefore, the historical land use from 1824 and 1882 was not considered for the LARSIM simulation. Some hydrometeorological parameters such as air humidity and evapotranspiration were not considered either because of their minor influence on discharges during such an extreme event. For other parameters like wind speed and sunshine duration, there was no or only fragmentary information available from the historical meteorological observations. Therefore, the LARSIM simulation was carried out with a parametrisation for the year 1993 and only the meteorological parameters temperature and precipitation were modified accordingly with the historical values from 1824 and 1882 . The flood event of 1882 was caused by rain and snow melt. The incorporated snow module in LARSIM, the threshold for air temperature below which precipitation falls as snow, was set to $+1.5^{\circ} \mathrm{C}$ (daily mean value).

\subsection{Interpolation of historical data for the 1824 flood event}

The most important parameter for the simulation of discharges with hydrologicals models is precipitation. One of the major difficulties in this regard is the determination of the areal precipitation. As the meteorological observations network of the $19^{\text {th }}$ century was by far not as dense as today, a straightforward interpolation of precipitation from the historical data would not incorporate the high spatial variability of this parameter. Therefore, similar weather patterns from modern data were analysed and compared with the historical situation during the floods of 1824 and 1882.

The idea is to find best matches at stations with historical and modern observation and to use the spatial pattern of the dense modern data as additional information for the interpolation of the historical precipitation data. The data sets were taken from German Weather Service (DWD) for the years 1934-2006. Due to the different data quality and quantity from 1824 and 1882, two different approaches were used for finding similar precipitation patterns and interpolation of the data.

For the case of the 1824 flood event, the best match regarding the precipitation pattern could be determined for 27 and 28 October 1998. This precipitation pattern correlates highly with the meteorological conditions of 28-29 October 1824. The weather course of October 1998 also caused heavy precipitation and floods in the Neckar catchment (LfU, 2000).

Assuming that the regional distributions of precipitation in October 1824 and 1998 have a high similarity, the regional precipitation pattern in the Neckar catchment for the flood event of 1824 was modelled in several steps (Fig. 4). Using the historical measurements and weather descriptions of 1824, the regional distribution for the strong precipitation of 28-29 October 1824 was determined by means of a regression model between seven historical precipitation measurements conducted in October 1824 by Schübler (1825) and measured precipitation values from 1998 at the same sites. The best result was achieved with a linear-logarithmic 


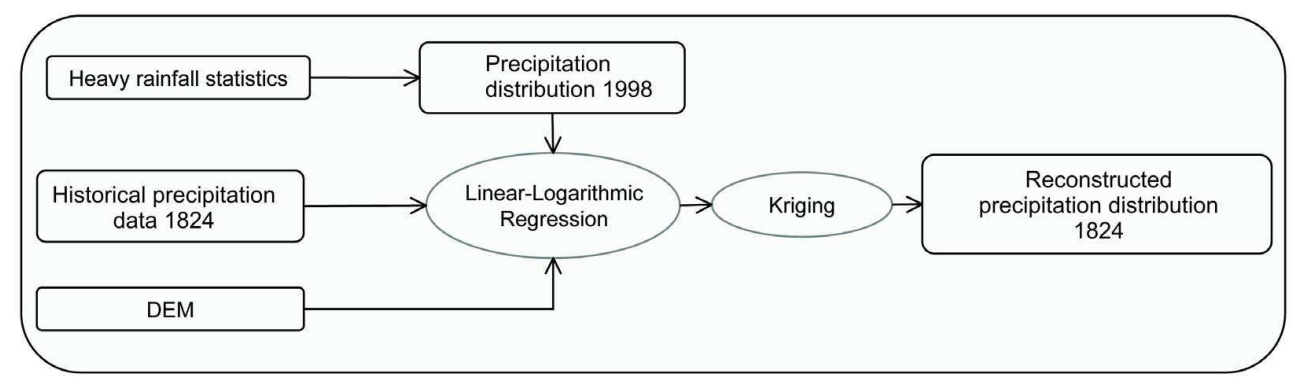

Fig. 4. Method for obtaining areal precipitation data for the 1824 flood event

regression using equation 2

$$
N_{1824}=\left(1.5+\frac{4}{\ln (D E M)^{4}}\right) \cdot N_{1998}
$$

where $\mathrm{N}_{1824}$ are the precipitation measurements in $1824, \mathrm{~N}_{1998}$ are the precipitation measurements at the same sites in 1998 and DEM is the elevation of these sites. This regression model yielded a $R^{2}$ of 0.88 and was used to modify the dense precipitation data for 1998 (i.e. 220 stations in the study area) to obtain enough values for the 1824 precipitation event for a reliable spatial interpolation. This was done using kriging interpolation to obtain a quantitative precipitation distribution ( $1 \mathrm{~km}$ grid) for the $36 \mathrm{~h}$ rainfall event of $28-29$ October 1824.

\subsection{Interpolation of historical data for the 1882 flood event}

In comparison to the flood event of 1824 , a dataset with daily temperature and precipitation measurements for the whole year of 1882 was available. Daily temperature grids from historical meteorological observations were derived by establishing a linear regression between altitude and daily temperature means for each station during the year 1882 on the basis of 22 reference stations in the study area. Afterwards, the digital elevation model (DEM) was multiplied in the form of

$$
T_{(x, y) i}=a_{i} \cdot \operatorname{DEM}_{(x, y)}+b_{i}
$$

where $\mathrm{T}_{(\mathrm{x}, \mathrm{y}) \mathrm{i}}$ is the temperature at the DEM raster cell with $x$ as latitude and $y$ as longitude; $a_{\mathrm{i}}$ and $b_{\mathrm{i}}$ are the derived daily regression coefficients and $i$ is the corresponding day of the year (DOY) in 1882. The reconstruction of a daily temperature grid was necessary because the 1882 flood event was caused by a combination of snow melt and precipitation and this had to be considered in the simulation of discharges.

Although the network of meteorological stations in south west Germany and the adjacent areas in France and Switzerland was relatively dense in the 1880s, the Neckar catchment had only data from eight stations from which daily precipitation and temperature readings were available. As a first step, a time series of daily precipitation patterns for the period 1 January to 24 December 1882 was created on the basis of the historical precipitation measurements, which was used as input data to simulate the discharge in the Neckar until the flood event. In order to capture the spatial variability of the flood triggering precipitation after 24 December 1824, 
a similar approach as in the the case of the 1824 flood event was applied. The aim was to find a comparable 3-day qualitative precipitation pattern for the period of 25-27 December 1882 but with a higher density of precipitation measurements. Five representative (i.e. spatially well distributed over the study area) stations were selected where daily precipitation data for 1882 was available. These stations are located in Freudenstadt, Villingen, Stuttgart, Buchen and Ansbach. A $5 \times 3$ matrix of precipitation data was created for the five stations and for the corresponding three days (25-27 December 1882). These data were normalized at the upper left value. In an analogical way, the time series of recent precipitation data for these five observation sites were compiled for the period 1958-2005, where data was available from the German Weather Service DWD for these stations. Each matrix of the moving window was normalized as described above and compared with the normalized historical matrix with a Kendall Rank Correlation test (c.f. Figure 5). With this non-parametric test, the degree of correlation of two samples, transferred to ranks, can be described. The Kendall Rank Correlation is calculated as

$$
\tau=\frac{n_{c}-n_{d}}{n(n-1) / 2}
$$

where $\tau=$ Kendall's Rank Correlation value, $n_{\mathrm{c}}$ is the number of concordant pairs, $n_{\mathrm{d}}$ is the number of discordant pairs and $n$ is the sample size. If Kendall's $\tau$ is 1 , the agreement of the two rankings is perfect; $\tau=0$ means complete independence of the rankings.

The flow chart in Figure 6 gives an overview on how the input data for the run-off simulation were derived.

\section{Results of the case study}

\subsection{Reconstruction of atmospheric circulation patterns and weather conditions in $\mathbf{1 8 2 4}$}

The circulation pattern for 26-30 October 1824 was identified as a cyclonic west situation (Wz), according to the weather classification of Hess \& Brezowski (Gerstengabe \& Werner, 1999). In October 1824, a low-pressure area over the British Isles, opposed to a high-pressure area over the Mediterranean, caused a strong pressure gradient that carried warm and humid air masses from the Atlantic into Central Europe, causing gales and thunderstorms with heavy precipitation over south west Germany (Fig. 7). The low-pressure system triggered heavy rainstorms in the northern and southern parts of the Black Forest.

\subsection{Reconstruction of atmospheric circulation patterns and weather conditions in $\mathbf{1 8 8 2}$}

In the year 1882, large parts of western Germany were hit by two large flood events. The first one, which is not part of this study, occurred at the end of November 1882 and affected mainly the lower course of the River Rhine. This flood event was caused by extraordinarily high rainfall amounts in the November of 1882, a maximum being between 23-26 November 1882. During the second half of December 1882, the weather was characterized by a strong high pressure area over Russia and Eastern Europe, which led to calm weather conditions in the study area. This is also well documented by the meteorological observations in the region. In some parts of south west Germany, this led to an atmospheric inversion with sunshine and higher temperatures in the mountain ranges and fog and lower temperatures e.g. in the Upper Rhine Valley and the area around Lake Constance. From the 21 December 1882 onwards, the circulation changed towards a meridional pattern, which brought cold air masses from the Northern Atlantic Ocean into Central Europe. This led to a decrease in air temperature 


\begin{tabular}{c|c|c|c|c|c} 
& Freudenstadt $\left(s_{1}\right)$ & Villingen $\left(s_{2}\right)$ & Stuttgart $\left(s_{3}\right)$ & Buchen $\left(s_{4}\right)$ & Ansbach $\left(s_{5}\right)$ \\
\hline 25 Dec $\left(d_{1}\right)$ & $35.0 \mathrm{~mm}$ & $18.3 \mathrm{~mm}$ & $7.1 \mathrm{~mm}$ & $30.3 \mathrm{~mm}$ & $0.2 \mathrm{~mm}$ \\
26 Dec $\left(d_{2}\right)$ & $55.9 \mathrm{~mm}$ & $32.5 \mathrm{~mm}$ & $10.5 \mathrm{~mm}$ & $33.7 \mathrm{~mm}$ & $21.4 \mathrm{~mm}$ \\
27 Dec $\left(d_{3}\right)$ & $74.8 \mathrm{~mm}$ & $20.3 \mathrm{~mm}$ & $5.3 \mathrm{~mm}$ & $33.2 \mathrm{~mm}$ & $16.1 \mathrm{~mm}$
\end{tabular}

$d_{1}\left(\begin{array}{ccccc}s_{1} & s_{2} & s_{3} & s_{4} & s_{5} \\ 35.0 & 18.3 & 7.1 & 30.3 & 0.2 \\ 55.9 & 32.5 & 10.5 & 33.7 & 21.4 \\ 74.8 & 20.3 & 5.3 & 33.2 & 16.1\end{array}\right)$

(1)

$d_{1}\left(\begin{array}{ccccc}s_{1} & s_{2} & s_{3} & s_{4} & s_{5} \\ 1.00 & 0.52 & 0.20 & 0.87 & 0.01 \\ 1.60 & 0.93 & 0.30 & 0.96 & 0.61 \\ 2.14 & 0.58 & 0.15 & 0.95 & 0.46\end{array}\right)$

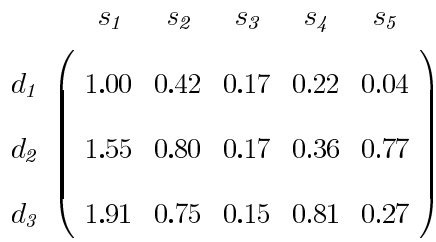

Fig. 5. Measured precipitation (25-27 December 1882) compared with modern precipitation data with the help of the Kendall Test 


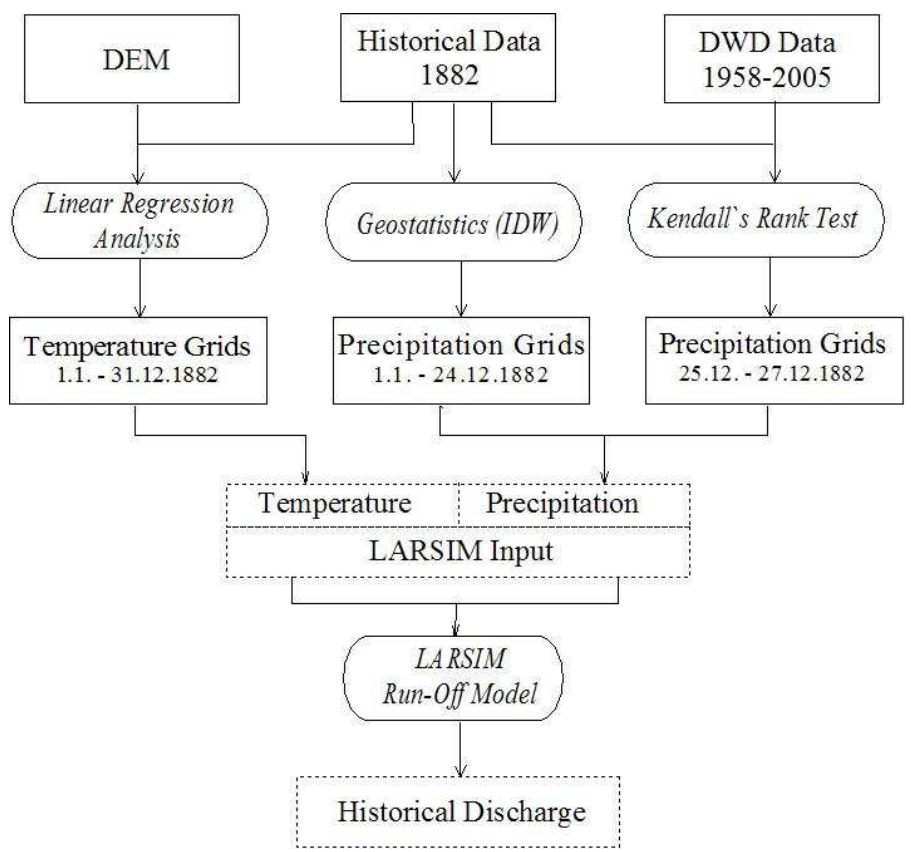

Fig. 6. Method for obtaining daily temperature and precipitation data for the 1882 flood event

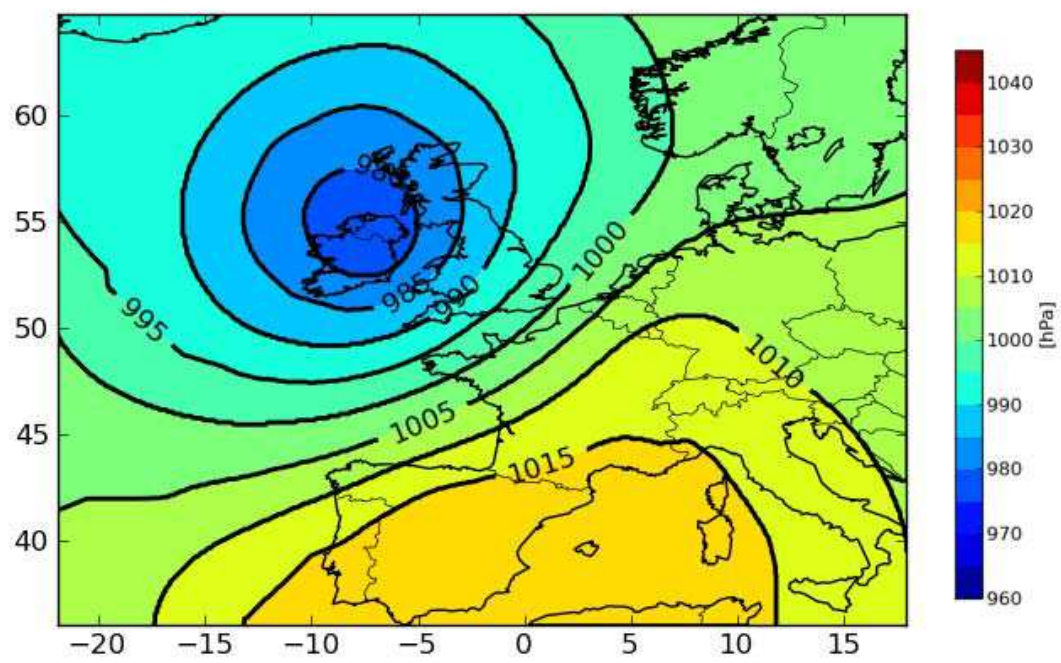

Fig. 7. Atmospheric circulation pattern over Central Europe from 26-28 October 1824 
and heavy snowfall in most parts of the study area. According to the meteorological data and the qualitative data from historical newspapers, the onset of the snowfall in south west Germany was between December 22 and 23. From 25 December 1882 onwards, the meridional circulation changed towards a zonal westerly pattern which brought warmer air masses into Central Europe (Fig. 8). This led to a rapid and strong temperature increase and long lasting rainfall. This caused the snow that had fallen the days before to melt. The combination of rainfall and snow melt led to devastating floods, especially in tributaries of the Rhine River. In some parts of the Neckar catchment, the water levels were only exceeded by the extreme flood event of 1824 (Bürger et al., 2006).
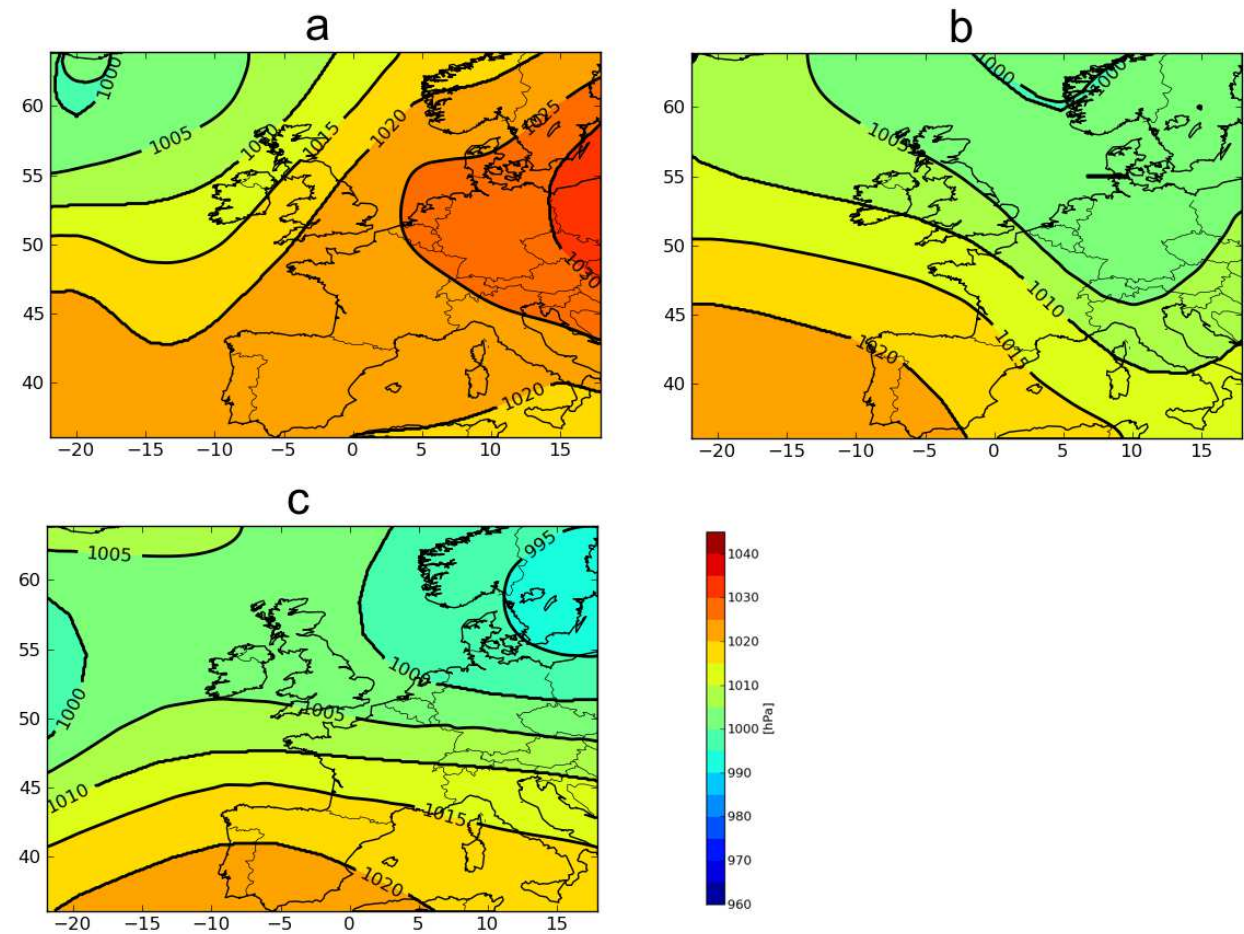

Fig. 8. Circulation patterns over Central Europe on (a) 20 December, (b) 23 December and (c) 26 December 1882

\subsection{Reconstructed precipitation pattern for 1824}

With the information of the historical data a distinct zonal weather condition with strong cyclonic characteristic could be detected for October 1824, which led to long lasting rainfall in Central Europe. For the detailed reconstruction of precipitation in the Neckar catchment for October 1824, the best corresponding weather situation for the years 1934 to 2004 was detected using the monthly weather forecasts of the German Weather Service (DWD) and the heavy precipitation statistics for southwest Germany (DWD, 2002). 
The weather pattern for the period 27 and 28 October 1998 correlates highly with the meteorological conditions from 26 to 28 October 1824. Assuming that the spatial distribution of the precipitation in October 1824 and 1998 has a high similarity, the regional precipitation pattern in the Neckar catchment for the flood event of 1824 was modelled in several steps.

With the historical measurements and weather descriptions of 1824, the spatial distribution of the precipitation event from 28 to 30 October 1824 was determined using the derived regression model. For the spatial interpolation of the precipitation, the measurements from 220 weather stations of the German Weather Service were linked in a geostatistical model with a digital elevation model (DEM) using Kriging Interpolation. The calculated values were used for geostatistical modelling of the quantitative rainfall distribution ( $1 \mathrm{~km}$ grid) for the 36 hour rainfall event from 28 to 30 October 1824.

From the modelled precipitation pattern for the Neckar catchment and its neighbouring areas (Fig. 9), it can be seen that the highest precipitation with values up to $230 \mathrm{~mm}$ in 36 hours occurred in the western crest of the northern parts of the Black Forest. This is approximately twice as much as the average precipitation amount for October in the climate standard period 1961-1990 (DWD, 2002). The lowest precipitation amount was determined for the area in the Upper Neckar Valley. This corresponds very well to the descriptive weather observations from various historical records in this area. The upper areas of the Neckar catchment were not so severely affected by the flood in 1824 as the areas in the Black Forest nor in the northern and eastern part of the Neckar catchment. The rainfall distribution can be explained by the atmospheric circulation pattern and local orographic features. Southwesterly air flows are typical for the region. In particular, the northern parts of the Black Forest frequently receive relatively high precipitation during such weather conditions due to the orographic features found on the western side of the Upper Rhine Valley.

\subsection{Reconstructed temperature and precipitation patterns for 1882}

Using Kendall's Rank coefficient test, the best match for a similar precipitation pattern was found for the period between 29-31 January 1983, which yielded a $\tau$ of 0.86 (c.f. Fig 5). For this period, the linear regression between the historical data and the identified recent pattern resulted in $R^{2}=0.93$ and a regression coefficient of 2.16. The 1983 data comprises more than 400 precipitation measurements within the study area. Precipitation grids were interpolated from this data and then multiplied with the regression coefficient of 2.16 in order to adjust the precipitation amounts for the situation for 25-27 December 1882. A correction of $+30 \%$ was applied for all historical precipitation data from 20 December 1882 onwards. This was necessary in order to account for measurement errors during snowfall and strong wind (Rapp \& Schönwiese, 1996). Information from contemporary newspaper reports states that the snow which had fallen from 22 December onwards had completely melted by the evening of 26 December. This information is also confirmed by the temperature data. Due to a change in the circulation pattern, warm air masses were transported to southern Germany from 26 December onwards. This led to a strong temperature increase in the study area of up to $10 \mathrm{~K}$ in 24 hours. As a consequence, the snow which had fallen from 22 December onwards melted completely, even in higher elevations above $1000 \mathrm{~m}$ in the Black Forest.

The total precipitation from December 25 to 271882 summed up to $180 \mathrm{~mm}$ in the Black Forest (c.f. Fig. 10). During these three days, the central parts of the Neckar catchment received relatively small precipitation amounts since this area is situated on the leeward side of the 


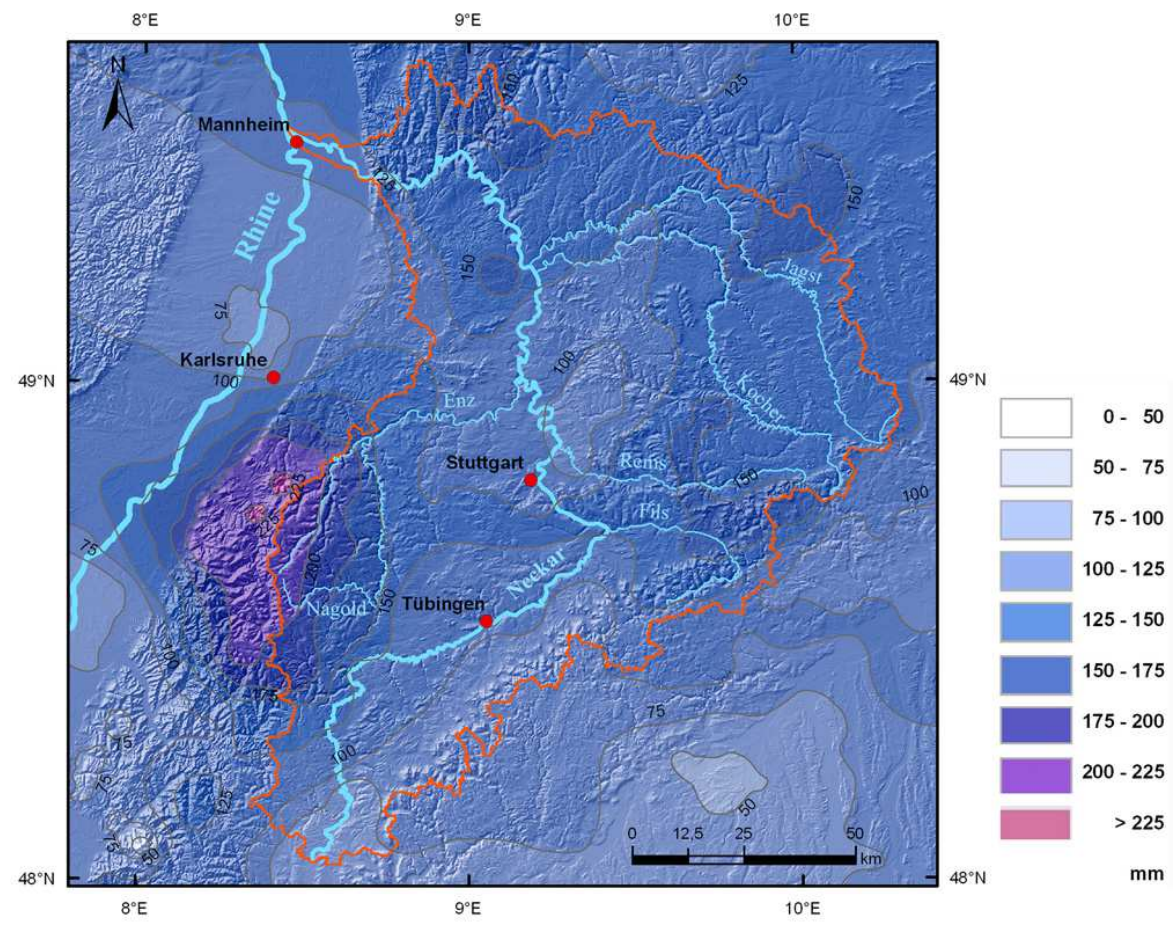

Fig. 9. Reconstructed areal precipitation for 28-29 October 1824

Black Forest and thus in the precipitation shadow during westerly circulation patterns. The combination of snow melt and the strong precipitation led to this extreme flood at the end of December 1882.

\subsection{Simulated discharges for the 1824 and 1882 flood events}

The reconstructed areal precipitation patterns were used as input for the water-balance model LARSIM to simulate the historical discharges. The simulated discharges along the course of Neckar during the flood events of 1824 and 1882 are shown in Figure 11 in comparison with the results from other sources like historical documents (Königliches Ministerium des Innern, 1896) and historical river cross profiles. These discharge values were derived from an analysis of water levels from historical river cross profiles carried out by Sudhaus et al. (2008) and were used to verify the results from the run-off modelling using the historical meteorological data. Furthermore, the values for the current design flood with a return time of 100 years $\left(\mathrm{HQ}_{100}\right)$ and the extreme flood scenario (HQextreme) also depicted (LfU, 2005).

The results for 1824 correspond well to the few discharge values which were found in historical documents. For example, in Bad Cannstatt (district of Stuttgart at river km 183), a discharge of $1320 \mathrm{~m}^{3} \mathrm{~s}^{-1}$ was recorded in a historical record for the 1824 flood. Local historical administrative reports recorded discharges between 4560 and $4800 \mathrm{~m}^{3} \mathrm{~s}^{-1}$ for Offenau (near Heilbronn at river km 98) and Heidelberg (river km 24) during the 1824 flood event (Sudhaus et al., 2008). The discharge values of 1824 in the Lower Neckar clearly exceed the values for 

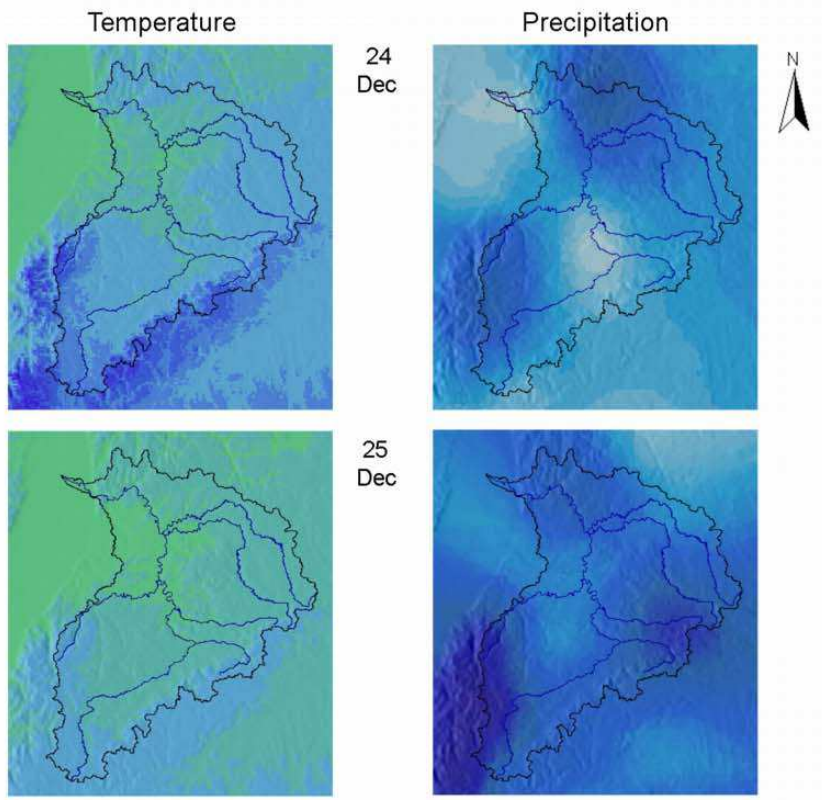

25
Dec
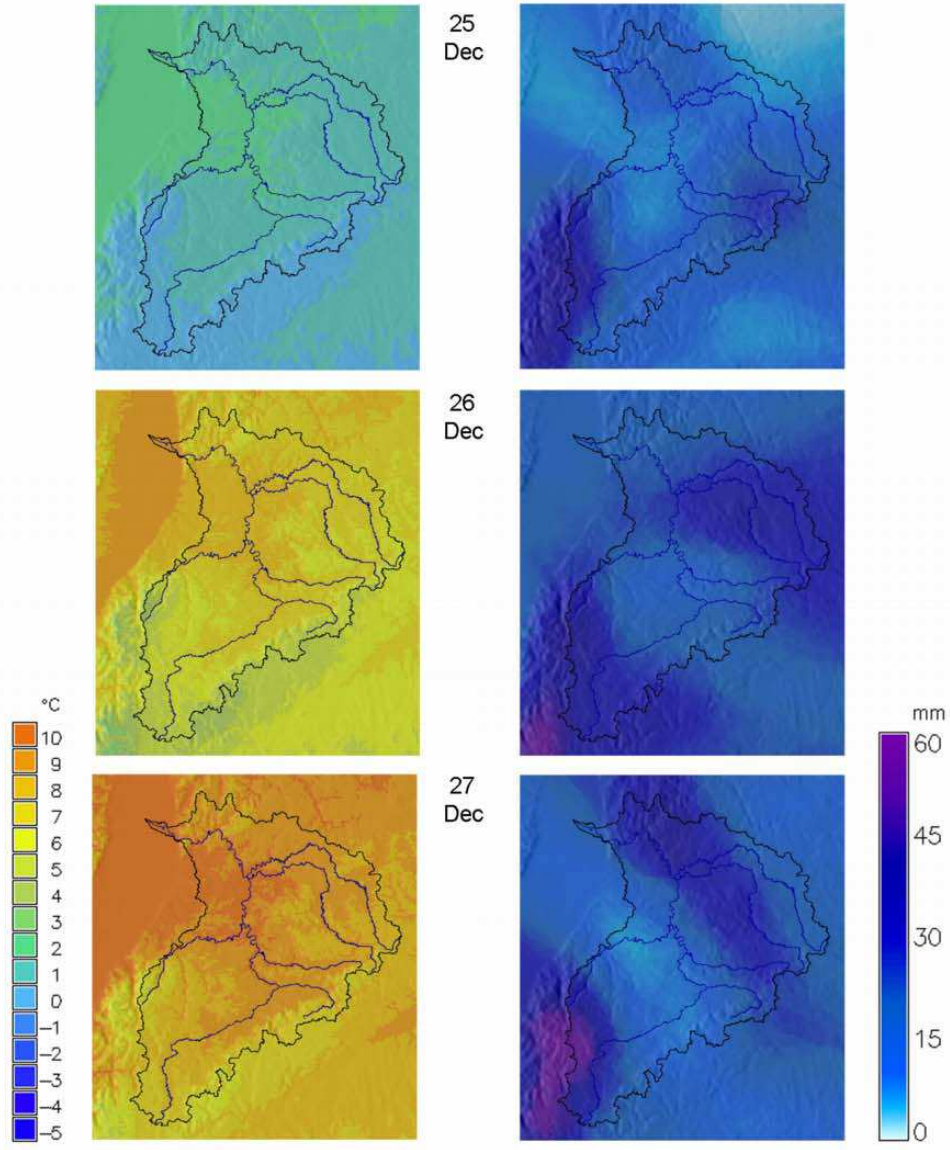

Fig. 10. Reconstructed temperature and areal precipitation for the flood event in December 1882 

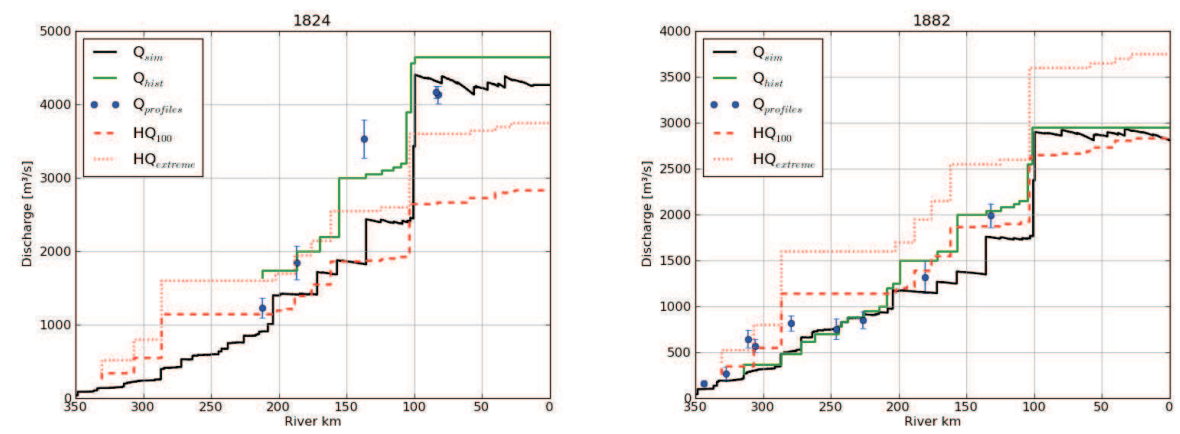

Fig. 11. Peak Discharges of the flood events in 1824 and 1882 along the Neckar River based on different data. $\mathrm{Q}_{\text {sim }}$ : Simulation with LARSIM-Model, $\mathrm{Q}_{\text {hist }}$ : Reported discharge values from historical sources, $Q_{\text {prof }}$ : Discharge based on historical river cross profiles (Sudhaus et al., 2008), $\mathrm{HQ}_{100}$ : Design flood with 100 year return period, $\mathrm{HQ}_{\text {extreme }}$ : Extreme flood scenario.

$\mathrm{HQ}_{100}$ and $\mathrm{HQ}_{\text {extreme. }}$ A flood event with the dimension of 1824 would have devastating consequences for the riparian owners. The flood event of 1882 in the lower course of the Neckar River is comparable with a 100 year flood (c.f. fig. 11).

\subsection{An example of using historical information for extreme value statistics}

The usual practice for determining return times of floods is to calculate these values with the help of extreme value statistics. A major drawback of this method is that the underlying discharge data (e.g. annual peak discharges) often comprise only a few decades, which do not necessarily represent the flood characteristics of a river. Apart from this, the choice of a distribution function and the time span covered by discharge data can have a major influence on the results of extreme value calculations. In the following example, we show how information from historical flood events can be included in statistical extreme value analysis by using the maximum likelihood method and by making assumptions about the maximum annual peak discharges for the years in between the historical events. For the Plochingen gauging station situated in the middle course of the Neckar River, annual peak discharge data are available from the observation period 1921-2006. The highest observed value in this time span was a flood event in 1978 with a peak discharge of $1150 \mathrm{~m}^{3} \mathrm{~s}^{-1}$. This data series was extended by incorporating peak discharge values obtained from the reconstruction of the historical flood events in 1824 and 1882, which yielded $1650 \mathrm{~m}^{3} \mathrm{~s}^{-1}$ and $1200 \mathrm{~m}^{3} \mathrm{~s}^{-1}$, respectively. Furthermore, the historical sources revealed information about a flood event in 1851 at this site, for which the peak discharge could be narrowed down to a range between 1200 and $1500 \mathrm{~m}^{3} \mathrm{~s}^{-1}$. These results individually show that all three major historical flood events in the $19^{\text {th }}$ century had higher peak discharge values than those of the observation period from 1921-2006. Furthermore, it can be concluded that for all other flood events in the time between 1820 and 1920, the annual peak discharge did not exceed the threshold value of $1190 \mathrm{~m}^{3} \mathrm{~s}^{-1}$ (otherwise such events would have been found in the historical records). Therefore, the annual peak discharge data can be extended back to the year 1800 by using the peak discharges from the three historical flood events (in case of the 1851 event also with the uncertainty range) and by assuming that a certain threshold level was not exceeded in all the other years in between (Fig. 12). 


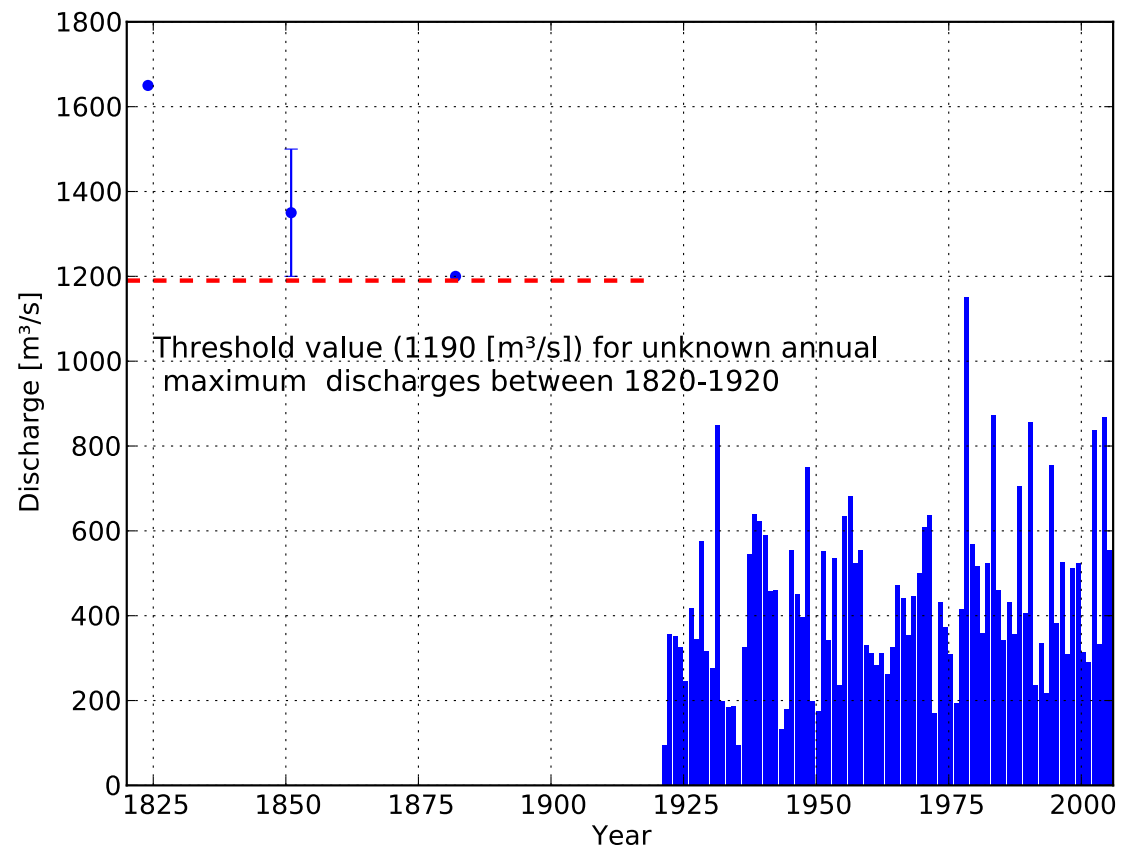

Fig. 12. Maximum Annual Discharges at the Plochingen Gauging Station (Neckar) for the Period 1820-2006

For calculation of the extreme value statistics based on the extended data series, the 2 parameter Gumbel-distribution was used. The location and scale parameters $\mu$ and $\beta$ were estimated using the maximum likelihood method. This method has the advantage that data with an uncertainty range and threshold assumptions can be used

$$
L(x, \mu, \beta)=\sum_{i}^{n} \ln f\left(x_{i}, \mu, \beta\right)+k \ln \left(F(T)+\ln \left(F\left(x_{\max }-F\left(x_{\min }\right)\right) \rightarrow \max \right.\right.
$$

where $\mathrm{T}$ is the threshold value (here $1190 \mathrm{~m}^{3} \mathrm{~s}^{-1}$ ) which was not exceeded within $\mathrm{k}$ years and $x_{\max }$ and $x_{\min }$ are the upper and lower boundaries (i.e. the uncertainty range of the peak discharge) of a specific event. The changes in return times when incorporating the historical information at the Plochingen gauging station are shown in Table 1.

\begin{tabular}{|c|c|c|c|c|c|}
\hline Data Basis & \multicolumn{5}{|c|}{ Peak Discharges [ m $\left.{ }^{3} \mathrm{~s}^{-1}\right]$} \\
& $\mathrm{HQ}_{10}$ & $\mathrm{HQ}_{50}$ & $\mathrm{HQ}_{100}$ & $\mathrm{HQ}_{200}$ & $\mathrm{HQ}_{1000}$ \\
\hline $1921-2006$ & 695 & 958 & 1069 & 1180 & 1436 \\
$1820-2006$ & 744 & 1033 & 1156 & 1278 & 1561 \\
\hline
\end{tabular}

Table 1. Peak annual discharges for return times at the gauging station Plochingen (Neckar) based on different data series 


\section{Discussion and conclusions}

The results for these two historical flood events have shown that there is no universal tool or method for reconstructing past flood events. The presented research is a closer view on single extreme events. An approach for reconstructing a historical flood event is always a process of dealing with the specific meteorological and hydrological circumstances as well as specific contemporary data and other relevant information for the river catchment which is under investigation. Analysing historical flood events has to be evaluated against reliable data and reliable references.

The results presented in this study show the potential of historical data for the reconstruction of flood events. A detailed analysis of flood events is generally possible if certain historical meteorological and hydrological data are available, which is usually the case for the past 150 to 200 years. This applies also to flood events where the distribution of meteorological stations is not very dense and unfavourable. With the modern analogue approach, it was possible to convert the historical data into gridded data sets which can be used for run-off modelling.

One deficit of the presented study is the need for hydrometeorological data in order to conduct such run-off simulations. In our presented case study, the data gaps could be closed using modern analogues. A very successful approach without such data or with a much lower number of direct data input is shown in the work of Barriendos et al. (2003) and Lobanova (2002), for example. They used indirect data like clerical reports concerning extreme flood or weather events to assess the intensity of hydrological extremes. But this approach is attended with time-consuming research in historical archives and still has low acceptance among decision makers.

The analysis of the flood triggering hydrometeorological conditions also revealed some interesting information. The flood events of 1824 and 1882 were quite different regarding their causes, intensity and characteristics. The extreme rainfall event at the end of October 1824 occurred when the soils were already more or less saturated by the previous weather conditions and was caused only by rainfall. The flood event in 1882 occurred when a combination of temperature increase and high precipitation at the end of December lead to snow melt and subsequently to high discharges. This weather situation is quite common in southwest Germany and caused a severe flood in 1993 in the Neckar catchment, for example. Unlike other severe historical flood events in the Little Ice Age which occurred after extraordinary winters (e.g. in 1784 or 1845), the flood events of 1824 and 1882 occurred under conditions which can also be expected nowadays or in foreseeable climate change scenarios.

The results of this study have also raised some questions regarding future work. One potential field of research is the development of new methods for the interpolation of precipitation, especially when only few data are available. This could be achieved by taking the local orography and the wind direction during the rainfall event into account. A second perspective would be to reconstruct long discharge times series based on large scale data such as atmospheric pressure fields, which are available on a daily basis from 1850 onwards. For this purpose, a downscaling approach can be used by establishing a connection between large scale atmospheric circulation patterns and discharge increments in the river catchment, as it has been done by Bárdossy \& Filiz (2005). With this method, phases of high and low flood frequencies can be detected which reveal information about the temporal and spatial flood variability in a certain river catchment. Furthermore, it would be interesting to investigate 
the transferability of the methods used in this case study to other river catchments in Central Europe.

\section{Acknowledgements}

The authors would like to thank the BMBF (German Federal Ministry of Education and Research) and the Federal State Ministry of Science, Research and Arts in Baden-Württemberg for funding this research work.

\section{References}

Ansell, T. J., Jones, P. D., Allan, R. J., Lister, D., Parker, D. E., Brunet, M., Moberg, A., Jacobeit, J., Brohan, P., Rayner, N. A., Aguilar, E., Alexandersson, H., Barriendos, M., Brandsma, T., Cox, N. J., Della-Marta, P. M., Drebs, A., Founda, D., Gerstengarbe, F., Hickey, K., Jónsson, T., Luterbacher, J., Nordli, Ø., Oesterle, H., Petrakis, M., Philipp, A., Rodwell, M. J., Saladie, O., Sigro, J., Slonosky, V., Srnec, L., Swail, V., García-Suárez, A. M., Tuomenvirta, H., Wang, X., Wanner, H., Werner, P., Wheeler, D., \& Xoplaki, E. (2006). Daily Mean Sea Level Pressure Reconstructions for the European North Atlantic Region for the Period 1850-2003. Journal of Climate Vol. 19 , No. 12, 2717-2742.

Bárdossy, A. \& Filiz, F. (2005). Identification of flood producing atmospheric circulation patterns, Journal of Hydrology, Vol. 313, No. 1-2, 48-57.

Barriendos, M., Coeur, D., Lang, M., Llasat, M.C., Naulet, R., Lemaitre F. \& Barrera, A. (2003). Stationarity analysis of historical flood series in France and Spain (14th-20th centuries). Natural Hazards and Earth System Sciences , Vol. 3, 583-592.

Benito, G., Lang, M., Barriendos, M., Llasat, M.C., Francés, F., Ouarda, T., Thorndycraft, V.R., Enzel, Y., Bárdossy, A., Coeur, D., \& Bobée, B. (2004). Use of Systematic, Palaeoflood and Historical Data for the Improvement of Flood Risk Estimation. Review of Scientific Methods. Natural Hazards, Vol. 31, No. 3, 623-643.

Bronstert, A., Niehoff, D., and Fritsch, U.: Auswirkungen von Landnutzungsänderungen auf die Hochwasserentstehung. Petermanns Geographische Mitteilungen, Vol. 147, No. 6, 24-33.

Bürger K., Dostal P., Seidel J., Imbery F., Barriendos M., Mayer H., \& Glaser R. (2006). Hydrometeorological reconstruction of the 1824 flood event in the Neckar River basin (southwest Germany), Hydrological Sciences Journal, Vol 51, No. 5, 864-877.

Centralbureau für Meteorologie und Hydrographie (ed.) (1889). Die Wassermengen der fliessenden Gewässer im Großherzogthum Baden. Beiträge zur Hydrographie des Großherzogthums Baden, 8. Heft, Berlin, Germany.

Dostal, P., Bürger, K., Seidel, J., Imbery, F., \& Sudhaus, D. (2007). Lernen aus der Vergangenheit. Historische Hochwasseranalyse. Ein Beitrag für den heutigen Hochwasserschutz. Berichte zur deutschen Landeskunde, Vol. 81, No. 3, 233-245.

Deutscher Wetterdienst. (2002). Deutsches Meteorologisches Jahrbuch 2002. DWD, Offenbach.

Gerstengabe, F.-W. \& Werner, P.C. (1999). Katalog der Großwetterlagen Europas (1881 - 1998). Nach Paul Hess und Helmuth Brezowsky. 5th edition, Potsdam \& Offenbach.

Haag, I., Gerlinger, K., \& Kolokotronis, V. (2005). Auswirkungen von Windwurfschäden auf Hochwasserabflüsse am Beispiel des Enz-Nagold-Gebiets. Wasserwirtschaft Vol. 10, 8-14. 
Honsell, M. \& Tein, M. (1891). Auftreten und Verlauf der Hochwasser von 1824, 1845, 1852, 1876 und 1882-83, In: Ergebnisse der Untersuchung der Hochwasserverhältnisse im deutschen Rheingebiet. Auf Veranlassung der Reichskommission zur Untersuchung der Stromverhältnisse des Rheins und seiner wichtigsten Nebenflüsse und auf Grund der von den Wasserbaubehörden der Rheingebietsstaaten gelieferten Aufzeichnungen, Centralbureau für Meteorologie und Hydrographie im Grossherzogthum Baden (ed.), Ernst, Berlin.

Königliches Ministerium des Innern (ed.) (1896). Verwaltungsbericht der Königlichen Ministerialabteilung für den Strassen- und Wasserbau für die Rechnungsjahre vom 1. Februar 1893/94 und 1894/95, Stuttgart.

Kundzewicz, Z.W. \& Brázdil, R. (eds.) (2006). Special Issue: Historical Hydrology. Hydrological Sciences Journal, Vol. 51, No. 5.

Lobanova, M. (2002). Application of past information for reducing flood risk (the case of Lensk city), In: Palaeofloods, Historical Data and Climatic Variability: Applications in Flood Risk Assessment, Thorndycraft, V.R., Benito, G., Barriendos, M. \& Llasat, M.C. (eds.), 231-236. CSIC, Madrid, Spain.

Ludwig, K. and Bremicker, M. (eds.) (2006). The Water Balance Model LARSIM - Design, Content and Applications. Freiburger Schriften zur Hydrologie 22, Freiburg, Germany.

LfU, Landesanstalt für Umweltschutz Baden-Württemberg. (2000). Das Hochwasser vom Oktober/November 1998 in Baden-Württemberg. Oberirdische Gewässer/Gewässerökologie 65 , Karlsruhe, Germany.

LfU, Landesanstalt für Umweltschutz Baden-Württemberg. (2005). Abflusskennwerte in Baden-Württemberg, Oberirdische Gewässer/Gewässerökologie 94, Karlsruhe, Germany.

Middelmann, M. (ed.) (2007). Natural Hazards in Australia: Identifying Risk analysis Requirements, Geoscience Australia, Canberra.

Ott, B. \& Uhlenbrook, S. (2004). Quantifying the impact of land-use changes at the event and seasonal time scale using a process-orientated catchment model. Hydrology and Earth System Science, Vol. 8, No. 1, 62-78.

Rapp, J. \& Schönwiese, C.D. (1996). Niederschlag- und Temperaturtrends in Baden-Württemberg 1955-1994 und 1895-1994, In: Wasser - Die elementare Ressource: Leitlinien einer nachhaltigen Nutzung, Lehn, H., Steiner, M., \& Mohr, H.(eds.), Springer, Berlin, Heidelberg, Germany, 113 - 170.

Seidel, J., Imbery, F., Dostal, P., Bürger, K., \& Sudhaus, D. (2009). Potential of historical meteorological and hydrological data for the reconstruction of historical flood events - the example of the 1882 flood in Southwest Germany. Natural Hazards and Earth System Sciences, Vol .9, 175 - 183.

Schübler, G. (1825). Über die ungewöhnliche Überschwemmung zu Ende Octobers des vorherigen Jahres und die dabei in verschiedenen Gegenden Württembergs Gefallene Regenmenge. Correspondenzblatt des Württembergischen Landwirthschaftlichen Vereins, Vol. 7, 191-198.

Sudhaus, D., Seidel, J., Bürger, K., Dostal, P., Imbery, F., Mayer, H., Glaser, R., \& Konold, W (2008). Discharges of Past Flood Events Based on Historical River Profiles. Hydrology and Earth System Sciences, Vol 12, 1201 - 1209.

Statistisch-Topographisches Bureau (ed.) (1883). Württembergische Jahrbücher für Statistik und Landeskunde, Stuttgart, Germany.

Straub, H. Historische Hochwasserinformationen und deren Nutzung. Arbeitskreis KLIWA (ed.), Kliwa-Berichte, Heft 10, 113-130, 2007. 


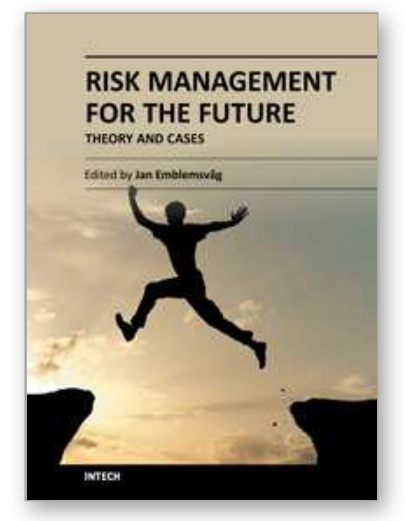

\author{
Risk Management for the Future - Theory and Cases \\ Edited by Dr Jan Emblemsvåg
}

ISBN 978-953-51-0571-8

Hard cover, 496 pages

Publisher InTech

Published online 25, April, 2012

Published in print edition April, 2012

A large part of academic literature, business literature as well as practices in real life are resting on the assumption that uncertainty and risk does not exist. We all know that this is not true, yet, a whole variety of methods, tools and practices are not attuned to the fact that the future is uncertain and that risks are all around us. However, despite risk management entering the agenda some decades ago, it has introduced risks on its own as illustrated by the financial crisis. Here is a book that goes beyond risk management as it is today and tries to discuss what needs to be improved further. The book also offers some cases.

\title{
How to reference
}

In order to correctly reference this scholarly work, feel free to copy and paste the following:

Jochen Seidel, Paul Dostal and Florian Imbery (2012). Analysis of Historical River Floods - A Contribution Towards Modern Flood Risk Management, Risk Management for the Future - Theory and Cases, Dr Jan Emblemsvåg (Ed.), ISBN: 978-953-51-0571-8, InTech, Available from: http://www.intechopen.com/books/riskmanagement-for-the-future-theory-and-cases/analysis-of-historical-river-floods-a-contribution-towardsmodern-flood-risk-management

\section{INTECH}

open science | open minds

\section{InTech Europe}

University Campus STeP Ri Slavka Krautzeka 83/A 51000 Rijeka, Croatia Phone: +385 (51) 770447

Fax: +385 (51) 686166 www.intechopen.com

\section{InTech China}

Unit 405, Office Block, Hotel Equatorial Shanghai No.65, Yan An Road (West), Shanghai, 200040, China 中国上海市延安西路65号上海国际贵都大饭店办公楼 405 单元 Phone: +86-21-62489820

Fax: +86-21-62489821 
(C) 2012 The Author(s). Licensee IntechOpen. This is an open access article distributed under the terms of the Creative Commons Attribution 3.0 License, which permits unrestricted use, distribution, and reproduction in any medium, provided the original work is properly cited. 